\section{BMJ Paediatrics Open}

\title{
Out-of-hospital deaths among children during COVID-19 pandemic: indicator of collateral damage?
}

\author{
Heini Harve-Rytsälä (D) , ${ }^{1}$ Laura Puhakka, ${ }^{2}$ Markku Kuisma, ${ }^{1}$ Mikael Kuitunen, ${ }^{2}$ \\ Jelena Oulasvirta (1D , ${ }^{3,4,5}$ Heli Salmi ${ }^{2}$
}

To cite: Harve-Rytsälä $\mathrm{H}$, Puhakka L, Kuisma M, et al. Out-of-hospital deaths among children during COVID-19 pandemic: indicator of collateral damage? BMJ Paediatrics Open 2020;4:e000763. doi:10.1136/ bmjpo-2020-000763

Received 11 June 2020 Accepted 30 July 2020
Check for updates

(c) Author(s) (or their employer(s)) 2020. Re-use permitted under CC BY-NC. No commercial re-use. See rights and permissions. Published by BMJ.

${ }^{1}$ Emergency Medicine and Services, University of Helsinki and Helsinki University Hospital Helsinki, Uusimaa, Finland ${ }^{2}$ New Children's Hospital, University of Helsinki and Helsinki University Hospital, Helsinki, Uusimaa, Finland ${ }^{3}$ Helsingin ja Uudenmaan Sairaanhoitopiiri, Helsinki, Uusimaa, Finland

${ }^{4}$ Faculty of Medicine, The University of Helsinki, Helsinki, Uusimaa, Finland

${ }^{5}$ Division of Anaesthesiology, Department of Anaesthesiology, Intensive Care and Pain Medicine, University of Helsinki and Helsinki University Hospital, Helsinki, Uusimaa, Finland

Correspondence to Dr Heini Harve-Rytsälä; heini. harve@helsinki.fi

\section{ABSTRACT}

We aimed to investigate the out-of-hospital mortality, and the actual prevalence of COVID-19 in children requiring paediatric emergency department (ED) care for infectious symptoms. There were four emergency medical services (EMS) responses concerning children (age 0-15 years) leading to death on-scene in 2 months during the pandemic, and eight during the previous 12 months in the Helsinki University Hospital area, although the number of EMS missions decreased by $18 \%$. The prevalence of COVID-19 in children contacting a paediatric ED for any infectious symptoms during the epidemic peak was only $2.7 \%$.

The infection control measures during the COVID-19 pandemic have inevitably had effects on children and their welfare. As COVID-19 is mainly mild in children ${ }^{1-3}$, they may not benefit from the infection control measures; thus, there is an increasing concern about causing collateral damage to children. ${ }^{4}$

A decrease in paediatric emergency department (ED) visits during the pandemic ${ }^{5}$ has raised a concern that parental worries over visiting healthcare could lead to delayed diagnosis of serious illness in children. Concurrently, the continuous presence of COVID-19 in media may create an illusion of a high prevalence of serious COVID-19 infections among children. Thus, diagnosis and treatment of common infections causing greater morbidity may also be delayed if healthcare professionals prioritise excluding COVID-19.

The aims of this study were to investigate the out-of-hospital mortality, and the actual prevalence of COVID-19 in children requiring ED care for infectious symptoms.

In March 2020 the Helsinki University Hospital (HUH) area (1 263000 inhabitants) formed an epidemic hotspot, and the government launched social distancing measures. Schools, preschools and most after-school activities were closed, social gatherings were limited and Southern Finland was isolated from the other parts of Finland. Health authorities recommended avoiding unnecessary ED contacts to prevent crowding of EDs and to limit transmission of SARS-CoV-2.

All out-of-hospital emergencies in the area are responded to by HUH emergency medical services (EMS). Advanced life support resuscitation is conducted on-scene, and, if unresponsive to resuscitation attempts, the patient is declared dead on-scene.

To investigate the out-of-hospital mortality, we retrieved all paediatric (age $0-15$ years) EMS responses leading to on-scene death in the HUH area from 1 March 2020 to 30 April 2020, and during the previous 12 months from 1 March 2019 to 29 February 2020 from the electronic patient record system (Merlot Medi, CGI Suomi Oy). In order to assess the prevalence of COVID-19 in acutely ill children during the local epidemic peak, we searched all 113 children contacting one of the two paediatric EDs of HUH for any infectious symptoms from 8 April to 15 April 2020.

The institutional research committee approved the study protocol $(\$ 24 / 2020)$. There was no patient and public involvement.

There were four out-of-hospital deaths in 2 months in 2020 compared with eight in the preceding 12 months (table 1). All were separate incidents. Three $(2.7 \%)$ of the 113 children contacting the paediatric EDs for infectious symptoms were positive for SARS-COV-2 RNA.

The prevalence of COVID-19 in children requiring $\mathrm{ED}$ care for infectious symptoms was low, but the number of sudden out-ofhospital deaths was noticeable. These findings do not justify advising families with acutely ill children to avoid paediatric ED contacts in order to prevent transmission of SARS-CoV-2.

Sudden out-of-hospital deaths in children are extremely rare, and thus it is difficult to find statistically significant differences for short periods. We find the increase in out-ofhospital deaths noteworthy, especially during 
Table 1 Characteristics of the EMS contacts with children (age 0-15 years) leading to on-scene death during the local peak of the pandemic (1 March 2020 to 30 April 2020) and the previous 12 months (1 March 2019 to 29 February 2020)

\section{March 2020 to 30 April 2020}

1 March

2019 to 29

February 2020

\begin{tabular}{|c|c|c|}
\hline $\begin{array}{l}\text { All EMS contacts with } \\
\text { children }\end{array}$ & 912 & 6673 \\
\hline $\begin{array}{l}\text { EMS contacts leading } \\
\text { to death on-scene }\end{array}$ & $4(0.44 \%)$ & $8(0.12 \%)$ \\
\hline Age (median, IQR) & $3.5(1.75-7.5)$ & $2(0-7)$ \\
\hline Traumatic aetiology & $3(75 \%)$ & $3(38 \%)$ \\
\hline $\begin{array}{l}\text { Unresponsive and } \\
\text { not breathing on } \\
\text { arrival of EMS }\end{array}$ & $4(100 \%)$ & $8(100 \%)$ \\
\hline $\begin{array}{l}\text { Previous medical } \\
\text { history with } \\
\text { comorbidities }\end{array}$ & $\begin{array}{l}1(25 \%) \\
\text { Mild } 1 \\
\text { Severe } 0\end{array}$ & $\begin{array}{l}2(25 \%) \\
\text { Mild } 0 \\
\text { Severe } 2\end{array}$ \\
\hline
\end{tabular}

EMS, emergency medical services.

a period when children were less exposed to for example, traffic hazards following social distancing measures. In addition, the overall number of EMS contacts with children decreased by $18.0 \%$ compared with the previous 12 months. These findings may suggest that the concern about seriously ill children presenting late during the pandemic is justifiable. Unfortunately, we cannot give detailed information about the causes of deaths, as the children could be identifiable.

Both our cohorts were small but regionally inclusive. As paediatric mortality or intensive care admissions due to COVID-19 have not been reported in Finland, ${ }^{6}$ we feel that the increase in sudden paediatric out-of-hospital deaths deserves further attention, and there is a need for more studies on the effects of the control measures on the health and welfare of children.
Contributors HH-R, HS, JO and MiK and MaK designed the study. Data collection was performed by JO, LP and HH-R. Data interpretation was performed by HH-R, $\mathrm{HS}, \mathrm{LP}$ and MaK. The initial version of the manuscript was drafted by HH-R, HS and LP. All authors revised, edited and contributed substantially to the critical revision of the manuscript. All authors read and approved the final manuscript.

Funding This study was supported by the Foundation for Pediatric Research (Lastentautien tutkimussäätiö), Finland, 4 September 2019 and Finnish Medical Society Duodecim, 23 April 2020. These funders had no role in the study design, in the collection, analysis and interpretation of data, in the writing of the manuscript, or in the decision to submit the manuscript for publication.

Competing interests None declared.

Patient and public involvement Patients and/or the public were not involved in the design, or conduct, or reporting or dissemination plans of this research.

Patient consent for publication Not required.

Provenance and peer review Not commissioned; externally peer reviewed.

Open access This is an open access article distributed in accordance with the Creative Commons Attribution Non Commercial (CC BY-NC 4.0) license, which permits others to distribute, remix, adapt, build upon this work non-commercially, and license their derivative works on different terms, provided the original work is properly cited, appropriate credit is given, any changes made indicated, and the use is non-commercial. See: http://creativecommons.org/licenses/by-nc/4.0/.

ORCID iDs

Heini Harve-Rytsälä http://orcid.org/0000-0002-0104-4553

Jelena Oulasvirta http://orcid.org/0000-0001-6750-4615

\section{REFERENCES}

1 Parri N, Lenge M, Buonsenso D, et al. Children with Covid-19 in pediatric emergency departments in Italy. $N$ Engl $\mathrm{J}$ Med 2020;383:187-90.

2 Lu X, Zhang L, Du H, et al. SARS-CoV-2 infection in children. N Engl J Med 2020;382:1663-5.

3 Choi S-H, Kim HW, Kang J-M, et al. Epidemiology and clinical features of coronavirus disease 2019 in children. Clin Exp Pediatr 2020;63:125-32.

4 Crawley E, Loades M, Feder G, et al. Wider collateral damage to children in the UK because of the social distancing measures designed to reduce the impact of COVID-19 in adults. BMJ Paediatr Open 2020;4:e000701.

5 Lazzerini M, Barbi E, Apicella A, et al. Delayed access or provision of care in Italy resulting from fear of COVID-19. Lancet Child Adolesc Health 2020;4:e10-11.

6 National Institute for Health and Welfare. Available: https://thl.fi/ fi/web/infektiotaudit-ja-rokotukset/ajankohtaista/ajankohtaistakoronaviruksesta-covid-19/tilannekatsaus-koronaviruksesta\#kuolemat [Accessed 9 Jun 2020]. 